\title{
The Impact of Baghdad-Berlin Railway on Britain's Nautical and Commercial Interests in Iraq's Rivers
}

\author{
Prof. Dr. Jamal Hashim Ahmad Dhuwaib \\ Dean. College of Education for Humanities, University oF Anbar-Iraq
}

Ammal Omer Khamee

M.A in Modern History

\begin{abstract}
With the beginning of 20th century, Germany emerged as a strong state after the unification of Germany in 1871 . It found itself behind the major powers in the field of colonialism. After the accession of Emperor William II the rule, he looked forward to gaining colonies and to get the ranks of major countries such as Britain and France. Germany has found in railway projects the means to achieve its ambitions. It has turned its attention to Iraq and the Arabian Gulf because of the enormous wealth that was there in Iraq. It also wanted to use it as a market for its products. Since Iraq and the Arabian Gulf were under the authority of Britain that had many interests in, as the road to India, it stood against the German penetration. As these areas were monopolized by Britain alone, it opposed the extension of the rail into Iraq and the Arabian Gulf.
\end{abstract}

Keywords: Baghdad,Berlin, Railway,Ottoman

\section{Introduction}

\section{Baghdad-Berlin Railways Project}

After Germany has achieved its national unity in 1871, it has emerged as a powerful state with great rapacity (Al-Assadi, 2001), particularly, after its economic development and the need for new markets for its products outside Europe (Abdul Aziz, 2007). This had culminated in investing its capitals in economically undeveloped countries (BOA, HR, SYS, /08/38/234-1903) and its attempts to build other colonies outside Europe (Al-Badaidi, 2011). The main focus of Germany in these concerns was in Asia, particularly, in the Ottoman State and Iraq to control their markets and raw materials (Al-Tikriti, C, 1966). Hence, Germany turned its attention to Iraq. And when General Von Moltke was working as an expert in the Ottoman army, he visited the Euphrates Valley and thought of what can be done there. Since then, he experienced an influence on the German orientation (BOA. HR. SYS, 95/32/23-3-1911), referring to the great fortunes in this region, especially, the agricultural sector (Al-Tikriti, $\mathrm{H}, 1985)$.

Germany thought of Iraq as an important source for raw materials and the food stuff it needs, especially, cereals (Shukri, 1994). On this basis, certain studies were conducted on the geography of Iraq, its potential fortunes and the navigation opportunities in its rivers. Thus, in the fifth decade of the nineteenth century, Karl Ritter dealt with the heights of the Euphrates valley (Salih, 1968).

Germany has conceived railways projects as the means which achieve its ambitions and interests in Minor Asia. These projects could encourage Germany to gain colonies whereby splendid areas will be open for it (BOA, HR, SYS, /08/38/234-1903). The economic deterioration and financial confusion in the Ottoman State provided a great opportunity for the German funders to build railways in this region (Aluzbaki,1977).

Since 1873, the Germans worked extensively in building railways in the Asian part of the Ottoman State (BOA. HR. SYS, 95/32/23-3-1911). In 1875, the German engineers built the first part of the Anatolian Railways as requested by the Ottoman 
government(BOA. HR. SYS, 95/32/23-3-1911). When Sultan Abdul Hammed II (1876-1909)(1) came to power, he showed a desire to build railways in the Ottoman state for political, strategic and economic goals. From the political and strategic perspectives, the Sultan would be able to move his troops in all the Anatolian region and the Mesopotamia. This would help him maintain security and order and give the Sultan a great power (BOA. HR. SYS, 108/38/23-3-1903). As for the economic side, the railways would increase the revenues of the Ottoman State and work to develop its economic sources (BOA. HR. SYS, 95/32/23-5-1911). Hence, all the obstacles facing the Germans were removed exploiting the relationship between Emperor William II(2) and Sultan Abdul Hammed II. This relationship has rapidly developed after the Emperor's visit to the Ottoman State in 1898 whereby the Sultan promised him to give the concession of building the railways to the Germans (Malhut, 2013).On his part, the Emperor expressed his support to the Sultan in the Islamic University Project and showed his pretentious protect to Islam (BOA. HR. SYS, 108/38/23-4-1903).

Sultan Abdul Hameed II appointed a board to discuss the means that facilitate building the railway and everything pertaining to this project. The board included Raoof Effendi, Minister of Trade, Hassan Effendi, Minister of General Labor, Mr. Wettendorf, Consultant of Ministry of Finance, Rachid Bay, Sultan Special Secretariat and Mr. Bertnam, Chancellor of Customs in addition to other prominent personnel. After certain investigations and discussions concerning the adoption of the best way that links Istanbul with Baghdad, the board suggested expanding the lines from Eski shehir to Konia then to Baghdad. The board thought that this line is useful since trading ships would be able to move from Shatt Al-Arab to Balis, which gives great facilities to transfer construction materials to build the railway. Moreover, this line would be significant in times of war to confront attacks using boat fleets (FO, 78, 3385, XIL00799).

The budget of the project was 16 billion pounds. However, due to the difficult situation of the Ottoman funders, the company would shoulder the financial expenditures of this line. As a compensation of the losses, the Ottoman State would grant the company the concession of mining in Arkali and Ciwas (FO, 78, 3385, XIL00799).

The starting point of the railway would be Izmir towards Eski shehir, then Kutahya then Konia towards Adana then Aleppo to finally reach Baghdad following the right side of the Euphrates. The building of this line would be divided into six sections and it would cross mounts, rocks, mountains, and valleys leading to several difficulties. The first section of the line is 225 $\mathrm{kms}$ in length and it starts from Izmir to Eski shehir. As for the second section, it is $200 \mathrm{kms}$ in length and it expends from Eski shehir to Kotahya then KarahHissar. The third section covers the region between KarahHissar and Konia to pass Rakman Valley towards Konia. It is $280 \mathrm{kms}$ in length. The fourth section goes from Konia to follow Kirman Valley and reach Arkali. The fifth section is $350 \mathrm{kms}$ and it starts from AoloKashla to Aleppo. Finally, the sixth section is $915 \mathrm{kms}$ in length and it goes from Aleppo to Baghdad following the right side of the Euphrates (3). Generally, the total length of the line from Izmir to Baghdad is $2200 \mathrm{kms}$ and it requires expenditures amounting to 15 million pounds (FO, 78, 3385, XIL00799).

In 1888, the Ottoman Company of Anatolian Railway was established (BOA. HR. SYS, 95/32/23-3-1911). This company worked on building the railway inside the Anatolia to The Bosporus with Ankara, which was completed in 1892 (Rafiq, 1978). In 1896, this line reached Konia (Kent, 1996) to reach Baghdad and a point on the Arab Gulf in 1899 through a concession to the Company of Anatolian Railway(BOA. HR. SYS, 95/32/23-3-1911). The company agreed to finish the railway within 8 years subject to any delays emerging from compelLynch circumstances such as a war between the European powers or the change in the monetary condition of the powers participating in building the railway (BOA. HR. SYS, 108/39/25-4-1903). On the fifth of March, 1903, the final concession, which was under negotiations for several years and was an outcome of a German-Ottoman understanding, was granted to Baghdad Railway. In principle, the concession represented a great victory to the German policy and its ambitions (BOA. HR. SYS, 108/38/23-4-1903). The line was linked to Baiji City to the north of Samara and it was opened in July, 1912 (Kashif Al-Ghitta, 1977).

\footnotetext{
1 - William II 1888-1918, was in that period the German Caesar. He is the son of Fredric and Queen Victoria of Britain. He received a meticulous military training in he exhibited a strong character. After two years of becoming the German Caesar, he fired Bismarck and sought a new policy in which he affirmed the right of Germany to lead the world. In 1914, he announced war on two fronts against Britain, France and Russia. In 1918, he stepped down after Germany was defeated in the war and was exiled from Germany. (Palmer, 1992).
}

2 - See appendix (1).

3 - See appendix (2). 


\section{Effect of the railway on the British navigation in Iraqi rivers}

At the beginning, Britain did not oppose the building of the railway in Minor Asia as long as the project is situated in regions far away from its interests. Supporting this stance, a British politician stated that Britain should not oppose the German ambitions and that Britain in a previous time was dreaming of building a railway in Minor Asia (BOA. HR. SYS, 108/38/234-1903). Hence, in 1872, Britain appointed a board led by Stafford Northcote who stated that building this line is of great significance in protecting India, yet, the project was disregarded (BOA. HR. SYS, 95/32/23-3-1911). However, the British stance towards the railway was changed after it conceived the effect of this line on its economic and trading interests in the Mediterranean towards the Arab Gulf, beside its effect on the strategic and political interests in the Arab Gulf towards the British influence in India (BOA. HR. SYS, 95/32/23-3-1911).

Building the railway was not restricted to the main line going from Berlin to Baghdad.Rather, the German company was given other concessions to build sub-lines, which raised the British fears. For instance, the company was given the concession to build a branch from Ossman on the Ottoman borders to Alexandria in Egypt and another branch on the Syrian coast (BOA. HR. SYS, 95/32/23-3-1911). The most dangerous of these on the British interests is the branch extending from Sadiji to Khanaqeen on the Iranian borders to meet the expected line in the middle of Iran. This would mean that the British trading which used to go from Baghdad to Iran (1), would be at a high danger (BOA. HR. SYS, 95/25/13-11911).

The fears of Britain began to emerge after the railway from Konia to Baghdad was completed, which means that the German trading control would be guaranteed for 400 miles from Istanbul to Konia and for 900 miles from Konia to Baghdad (BOA. HR. SYS, 95/32/23-5-1911). There might be some cargoes ready for shipping from Baghdad to Istanbul (BOA. HR. SYS, 108/38/23-2-1903). Britain realized that the Germans' goal was not only commercial, rather, it was political. Hence, Germany experienced a great influence on the Topkapi Palace in an attempt to gain a political influenceand commercial domination in the Ottoman regions(BOA. HR. SYS, 95/32/23-5-1911). As a result, this would put several obstacles in front of the British interests in Iraq and the Arab Gulf(Persian Gulf, 1920).

After the railway would reach Baghdad (2), Britain opposed its extension to Basra as this would affect the British navigation interests. Arguing on this point, Lord Curzon (3) stated that "navigation in Basra was in the hands of a British company for several years. I am afraid that this will be blocked in recent years". In another statement, he said "I believe that river navigation in Basra and Baghdad belong to us". (4) (BOA. HR. SYS, 95/32/23-3-1911).

Transportation by trains is given preference to transportation by ships because the former is faster. (BOA. HR. SYS, 109/22/11-2-1911). Hence, after Lynch ships used to travel from Baghdad and Basra within four or five days because the river way is zigzagging, water flow is always unstable, and because of sand mounts (Ekinci, 1999), the train can travel the same distance in one day in different climate conditions even when loaded with goods and passengers (Earle, 1924).

\footnotetext{
1 - See appendix (3).

2 - he was born on the $10^{\text {th }}$ of January, 1859 in Kedleston Hull in Berbyshire in Britain. In 1882, he graduated from Oxford University. In 1883 , he became the special secretary of Lord Salisbury. In 1886, he became a member in the common council and wad interested in safeguarding the British colonies and strengthening its influence. In 1891, he was appointed the deputy minister of India, then he became the deputy minister for the British foreign office for the years 1895-1898. He became the deputy in India. (Al-Ahbabi, 2011).
}

3 - in 1834, Britain sent a delegation to the Euphrates which was culminated in building a commercial chamber in Baghdad in 1842 by Hennery Polis Lynch and his brother Thomas Gera Lynch. in 1861, this chamber was developed into an international company which began sending steamships between Baghdad and Basra and working in internal trading. (Nawar, 1968).

4 - Shut Al-Arab contains great sediments coming annually from Karun River from the Iranian mountains. These sediments formed a block that took the crescent from extending for $(5-9,22)$ KIms from Faw towards the Arab Gulf. (Al-Mudaris, nd). 
Moreover, transportation by trains is more comfortable, secure and systematic. (BOA. HR. SYS, 109/22/11-2-1911). In addition, it is cheap, which affects the British trading sector. (BOA. HR. SYS, 95/32/23-3-1911). Thus, transportation by trains would destroy river transportation (BOA. HR. SYS, 110/20/18-8-1911). Furthermore, the train capacity is higher than that of the steamships. A train can carry four time or more of what the ship can (Ssada Babel, 1911).

According to items 9 and 23 of the concession, Baghdad Railways Company was given the right to use commercial ships and wind boats in Tigris, the Euphrates and Shatt Al-Arab to transport construction materials and equipment required for building the railway. (Frasers, 1909). Moreover, the company was given the right to build ports in Baghdad and Basra (BOA. HR. SYS, 110/11/21-3-1911). This represented a threat to Lynch Company and made Baghdad Railway Company a partner in the great profits coming from transporting goods between Baghdad and Basra with high costs imposed without a supervision (Ibraheem،1991). Therefore, Britain suggested that in case a British company would build the line from Baghdad to Basra, Britain would have free navigation in Tigris and the Euphrates (BOA. HR. SYS, 108/38/23-2-1903). Nevertheless, Britain refused to participate in the project under the pretext of lacking fair terms that give it the major part of domination in Baghdad-Basra section and absolute control on the end of the railway (BOA. HR. SYS, 110/20/1-5-1911).

Sir Edward Grey stated that the development of the British commerce does not depend on building Baghdad-Basra railway which probably suited the Ottoman desire for military and strategic reasons. It also did not guarantee a better and faster post service to Britain than that of Suez road, it only spares some time. Furthermore, Britain has river service that maintains faster and cheaper transportation for the British trading than the railway.(BOA. HR. SYS, 110/20/25-3-1911).

Britain insisted that the commercial end of the line should be Basra. On this basis, Fraser stated that "we always insist that the end of the line should be Basra, and transportation between Baghdad and Basra using the river will continue in the current situations. Moreover, steamships can carry big cargoes of goods and commodities without the railway affecting them, particularly, when the river paths will be improved and irrigation works will be completed. The only obstacle to change Basra surrounding to a port able to contain steamships coming from Suez Channel is the cape at the mouth of Shatt AlArab (1). However, this can be treated by shoveLynch and cleaning processes as well as building main platforms so that the city becomes an important trading center". (BOA. HR. SYS, 110/20/1-5-1911).

On the $14^{\text {th }}$ of August, 1912, an agreement was made between the German bank and Lynch Company to set forth transportation terms. However, the Ottoman government objected this agreement because it is against the terms of the concession right. Therefore, the German company Lynch suggested indulging the Ottoman company in the agreement and establishing a new Belgium company which undertakes negotiations and agreement with the Ottoman government to transport the construction materials. (BOA. HR. SYS, 111/23/14-8-1912). This company was called River Transportation Company in the East. Its capital which amounts to 1,500,000 million Francs comes Lynch Company and the German Bank (Lughat Al_Arab, 1912). The former Ottoman minister informed the Ottoman government about the talks between Baghdad Railway Company and Lynch to make an agreement to transport the equipment of the railway and stop the objection raised by Lynch and Britain against the project of Baghdad railway and the German company. He informed it, moreover, that the German Bank manager Gwiner was thinking that through this agreement, it is probable that the hostility of the British financial offices to the German project will end via indirectly providing a sum of money to Lynch, one of the main opposition bodies to this project. (BOA. HR. SYS, 111/23/14-8-1912). However, the 1912 agreement did not coincide with the British interests as it did not increase the British domination in the Iraqi rivers. (Ssada Babel, 1914). This agreement was not executed as it was canceled in 1913.

\section{The British stance towards the German attempts to extend the railway from Basra to the Arab Gulf}

After the line reaches Baghdad, Germany wanted to extend it to the Arab Gulf and build a port in Kuwait. However, Britain objected fearing that this would affect its commercial and strategic interests. Britain considers the Arab Gulf a crossing gate to India and when Germany builds a railway across the Arab Gulf, this would weaken the British status there. Britain had been in the Gulf years ago and it had interests and agreements and accords with the Sheiks there. Therefore, it will not allow Germany to penetrate the Arab Gulf. Hence, Lord Curzon argued that "I do not wish the railway to be extended from Baghdad to the Arab Gulf as this will lead to great damages to our trading and strategic interests there. I am not sure that our trade would benefit from building this line, on the contrary the line would do harm to our trade. In addition, I do not wish the line to go further than Baghdad. I am afraid that even if the line is built, trading would still be through steamboats. Our

${ }^{1}$ Aslan or Arslan in Turkish means Lion in English. 
political interests are not restricted in the Gulf only, or from the Gulf to Basra, or from Basra to Baghdad, they extend in the whole region until Baghdad." (BOA. HR. SYS, 95/32/23-3-1911). Hence, the principle of the British policy is not allowing the growth of any rivalry political influence in the Gulf water without a recognition from Britain. (BOA. HR. SYS, 95/32/235-1911).

As for the effect of the railway on Britain commercial interests, a gloomy picture was drawn of the future awaiting the British and Indian trading, which amounts to 1000000 pounds. It uses the ships throughout the Gulf to be delivered to Baghdad by steamboats through Tigris then by convoys to Iran. The British and Indian trading to Baghdad amounted to $90 \%$. (BOA. HR. SYS, 95/32/23-3-1911).

Britain realized that the German goal in Kuwait is political, not commercial, and building a port there requires high costs. Hence, the question is why Germany wishes to go to Kuwait and build a line across the desert to be used for commercial purposes? The only probable reason is that it wishes to penetrate the Arab Gulf to threaten the British status there, notwithstanding the British suspicions concerning the German intent to build a port in Kuwait to serve the railway that extends from the Bosphorus to that port. (BOA. HR. SYS, 110/20/1-5-1911). A British politician mentioned that even if the port was built in Kuwait, commercially several ships would use the river to Basra and carry cargoes below Baghdad instead of using the railway. However, politically, Britain would find its status in the Gulf threatened and its colony in Kuwait weakened.(BOA. HR. SYS, 110/20, 18-8-1911).

Should the railway be extended to the Arab Gulf, Britain thought of indulging other European countries with Germany fearing the hegemony of the latter on the project, notwithstanding the fact that Germany had plans to develop great parts of Iraq. (BOA. HR. SYS, 95/32/23-3-1911).

After certain negotiations and discussions concerning extending the railway to the Gulf, the Ottoman government suggested in 1910 the establishment of a new company to build the end of the railway. The Ottoman would have a share of $40 \%$ in this company and each of Britain, Germany and France would have a share of $20 \%$. A port would be built at the end of the railway and it would be under the control of the new company. Moreover, trading would be free and unconditional for all nations. Should the lines be extended to Kuwait, this should be done on agreement between Britain and the Ottoman government alone under certain terms. (BOA. HR. SYS, 11/25/29-7-1911). However, Britain refused this proposal and Freezer stated that "What is the benefit Britain can get from a company the biggest share of it is at the hands of the Ottomans and the Germans." Therefore, Britain insisted that the end of the line should be Basra. In case the railway is extended to the Gulf, Britain should have absolute control on the its end. (BOA. HR. SYS, 110/20/1-5-1911).

The other threat of Baghdad railway on the British commerce comes through the promise of the Ottoman government to Baghdad-Berlin Railway Company to pay the expenses of the railway lines as a kilometric warranty via raising customs fees. However, the British government announced that it was unable to increase the customs fees as this increase would lead to facilitate building the railway which has a harmful effect on the British commercial interests long established in Iraq. (BOA. HR. SYS, 110/6/13-3-1911). For instance, Lynch wrote a memorandum to the British foreign minister Edward Grey in which he stated that the Ottoman government was able to get rid of administering debts in 1907. Therefore, increasing customs fees would guarantee a yearly sum of money of about 450,000 to 500,000 pounds. Moreover, the Topkapi Palace would do the best to apply these fees which were devoted to pay the deficiency in the balance of the Macedonian states and to find shares for the German capitalists in Baghdad-Berlin railway. He asked Edward Grey not to agree to pay these fees. (BOA. HR. SYS, 108/55/24-7-1907). Accordingly, the British government in these conditions would not agree to increase the Ottoman customs fees unless a satisfactory conciliation will be concluded concerning navigation and a solution for the end of the railway would be found so that the British interests in Iraq and the Arab Gulf would be guaranteed (BOA. HR. SYS, 111/25/29-7-1911).

\section{The German Navigation Activity in Iraq and the British Stance}

In 1896, Germany established Wonckhaus Company, after its founder Robert Wonckhaus, as a nucleus in the Arab Gulf (Al-Assadi. 2001). To keep pace with the increase in the German transportation processes in Iraq, it was obliged to depend on a new navigation line in addition to the other German lines. Moreover, it depended on a new navigation line for the French and British transportations through Bombay (Al-Jurani, 2002). For that purpose, in 1906, it built the HamburgAmerica line and steamships started using this line to Basra in the same year. This had ended the monopolization of the British navigation lines of sea transportation (Al-Saadoon, 2006). Moreover, it had caused a competition between the two 
parties which led to decreasing transportation fees. For instance, Germany began paying less for transporting goods to Basra than that it used to pay to the British companies (Al-Samaraai, 1973). Furthermore, cargoes of the German ships to Basra port ranked the second after the British ships. The German commercial activity led to increasing transportation processes by Lynch Company between Basra and Baghdad (Salih, 1968). As a result of increasing the German commercial transportation processes to Iraq, Robert Wonckhaus Company was obliged to move its headquarters from Bushaher to Basra so that the Hamburg-America Line there stopped (Al-Jurani, 2002).

The Hamburg-America Line was supported by the German government which shouldered its funding through The Deutche Orient Bank (Al-Assadi, 2001). And to show the size of the German-Iraqi commercial transportation, Basra German Commercial Agency informed the commercial companies in Baghdad in April, 1906 that the three steamships affiliated to The Hamburg-America Line were no longer able to transport more cargoes (Al-Jurani, 2002). Thus, Britain feared the German threat to its commercial and navigation interests in the south of Iraq, particularly, after the German attempted to establish navigation interests in the Iraqi rivers (Oinham, 2004). For instance, F-Moral, representative of the German Commercial Chambers, attempted to win two concessions from the Ottoman government to build a navigation line on Tigris. In addition, the German ambassador in Istanbul showed the interest of his government in building navigation interests on Tigris and the Euphrates (Hasan, 1975). Moreover, Nicholson, the British Minister for Foreign Affairs, described the German attempts to conquer the region in the Mesopotamia saying that "the German automatically controlled Baghdad railway and they were seeking a control over the river navigation as well. If they win the oil concession in the Mesopotamia and Iran, they would not fail gaining big political influence at the expense of Britain in regions of utmost significance for India (Hiller, 1996).

The British warships were observing the German activity in Shatt Al-Arab. They used to apply medical detention and inspection on ships entering the river under the pretext of protecting this river from pirating actions (Al-Assadi, 2001).

As a result of the expansion of the German influence in the regions under the British control, a British politician stated that "The danger threatening our trade is not the competition of the railway for river transportation. It is that we are expecting a German attack in the future. The German will be heading to Iraq. The railway will bring the German settlers and between Baghdad and Mosul, about 20 stations will be built. Each of these will represent a nucleus for a German settlement. Moreover, the German chose the locations that contain minerals such as oil, iron and sulfur. We expect that the German arrivals in the region will be tremendous within the coming few years. It is time now to gain new concessions from the Ottoman Government by adding a new steamship and coaches for each ship. We also have to urge the Ottomans to merge their steamships within Lynch Company. The suffering of the British trading should not continue further and the Ottomans do not have the money to put new ships in Tigris. Hence, they should accept the aid from somebody. This help cannot be better than that of Britain. Britain in Istanbul should awake". (BOA. HR. SYS, 110/20/16-8-1911).

\section{Results}

Germany used the railways as a means to penetrate the east and gain colonies. It directed its attention towards Iraq dreaming of its fortunes, particularly, the oil.

The Ottoman state represented by Sultan Abdul Hammed II welcomed building the railway for its political and economic significance. Economically, the railway would add an additional revenue for the Sultan's safe. Politically, the railway will facilitate the mobilization of the military troops to maintain security.

Germany experienced a great pressure on the Topkapi Palace because it was trying to gain commercial control and political influence. When the Ottoman state becomes weak, Germany will control its fortunes.

Building the railway leads to a great damage to the British commercial, political and strategic interests, which means removing Britain from the top position.

The British blocking of any project which threatens its trade and status represents a proof of the size of the influence it reached.

The Ottoman state's agreement to build foreign projects on its lands opened the way for the foreign penetration and, consequently, caused the collapse of the Ottoman state. 


\section{Appendices}

Appendix (1): Map showing the locations which Baghdad-Berlin Railway crosses (BOA.HRT, 1225/1)

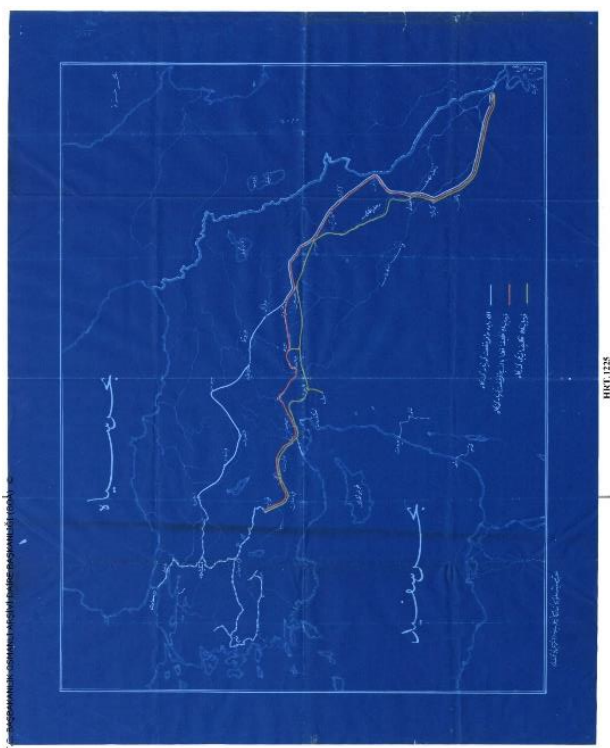

Appendix (2): Map of Baghdad-Berlin Railway (BOA.HRT. 1614/2/ 2-4-1911.

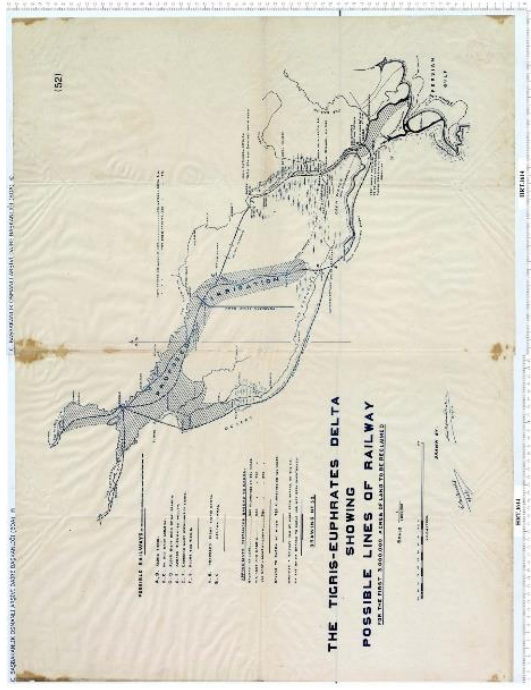


Appendix (3): Map showing borders of Basra with the Arab Gulf and Persia. (BOA. HR. SYS, 96119).

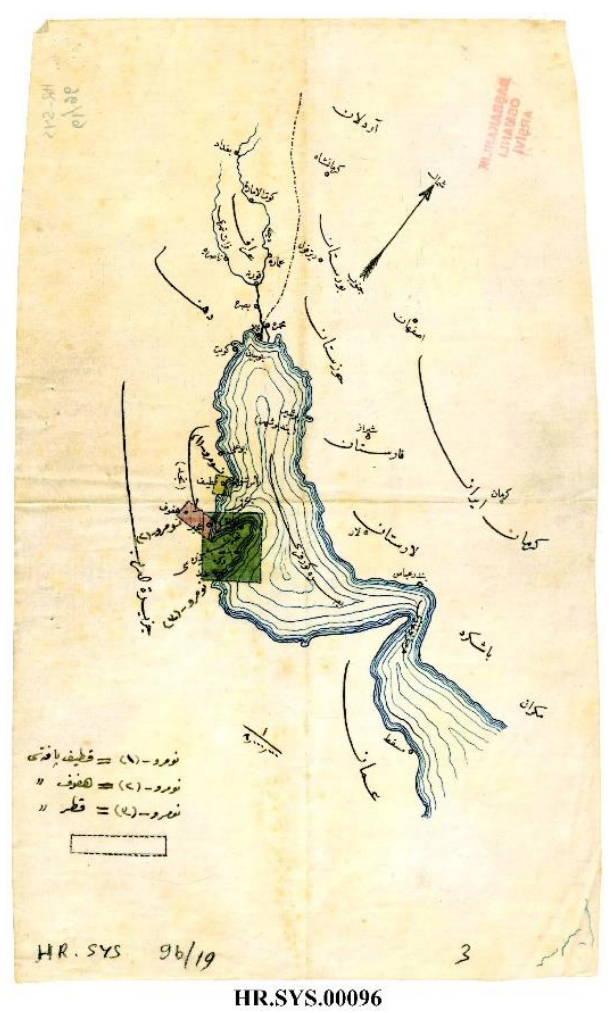

\section{References}

\section{Unpublished documents}

[1] The Ottoman:Başbakanlik Osmanli Arşivi (Abbreviated as B.O.A).

[2] BOA. HR. SYS, 108/38/23-4-1903.

[3] BOA. HR. SYS, 108/38/23-2-1903.

[4] BOA. HR. SYS, 108/39/25-4-1903.

[5] BOA. HR. SYS, 108/55/24-7-1907.

[6] BOA. HR. SYS, 109/22/11-2-1911.

[7] BOA. HR. SYS, 110/11/21-3-1911.

[8] BOA. HR. SYS, 110/20/1-5-1911.

[9] BOA. HR. SYS, 110/20/16-8-1911.

[10] BOA. HR. SYS, 110/20/18-8-1911.

[11] BOA. HR. SYS, 110/20/25-3-1911. 
[12] BOA. HR. SYS, 110/6/13-13-1911.

[13] BOA. HR. SYS, 111/23/14-8-1912.

[14] BOA. HR. SYS, 111/25/29-7-1911.

[15] BOA.HR.SYS,95/25/13-1-1911.

[16] BOA. HR. SYS, 95/32/23-3-1911.

[17] 16-BOA. HR. SYS, 95/32/23-5-1911.

[18] The British: Foreign Office (F.O).

[19] FO, 78, 3385, XIL00799, Baghdad Railway, No. 425, 10, May, 1882.

\section{References in Arabic}

[1] Al-Saadoon, Khalid Hamood, Tribal situations in Basra state during the late Ottoman era and British occupation 1326-1337. Al-Dar Alarabya for encyclopedias, Beirut, 2006.

[2] Salih, Zaki. Britain and Iraq until 1914. Al-Ani press, Baghdad, 1968.

[3] Al-Samaraai, Saed Abood. An introduction to the economic history of Iraq. Al-Fadha press, Najaf, 1973.

[4] Al-Tikriti, Salem Taha, Conflict on the Arab Gulf. Ministry of culture and guidance, Baghdad, 1966.

[5] Nawar, Abdulaziz Sulaiman. British interests in Iraqi rivers 1600-1914: A documentary study of the developments leading to the British monopoly of navigation in Iraq. Anglo-Egyptian library, Cairo, 1968.

[6] Ibraheem, Abdulfatah, on the road to India. Ministry of culture, Damascus, 1991.

[7] Rafiq, Abdulkarim. Arabs and Ottomans 1516-1916. Al-Sarooji press and library, Aka, 1978.

[8] Raynham, Maxfon. From the Mediterranean to the Arab Gulf. Trans. Mahmood Kibibo. Revision and preface, Majid Shbir, Dar Al-Waraqeen, London, 2004.

\section{$\underline{\text { Theses and dissertations }}$}

In Arabic:

[1] Hasan, Jasim Muhammad. Iraq during the Abdul Hameed Reign 1876-1909. Unpublished MA thesis, Faculty of Arts, Baghdad University, 1975.

[2] Al-Ahbabi, Abdulwahab M. Hasan, Lord Kirzin, the Deputy King in India 1899-1905: A historical study of his foreign and home administration. Unpublished MA thesis, College of Education, Tikrit University, 2011.

[3] Shukri, yasin Shihab. Baghdad State 1872-1909: A study in its economic and administration situations. Unpublished MA thesis, College of arts, Mosul University, 1994.

\section{$\underline{\text { In Turkish }}$}

[1] Ekinci,Ilhan,Osmanli devleti'n debazinehirvegoller devapurislet metesebbusleri, ArayiSlarinsanbilimeri, Arastirmalari-yil:1, sayi:2, 1999.

[2] Malhut,Mustafa, Mezopotamya Uzerindeingiliz-Alman Nufuz Mucadelesi, Tarih Okulu, Sayi XIV, 2013.

\section{References in English}

[1] Earle, Edward Mead, Turkey, The Great Powers, and the Baghdad railway,

[2] A study in Imperialism, London, 1924. 
[3] Frasers, David, The Short Cut to India, London, 1909.

[4] Kent,Marian, The Great Powers and the End of the Ottoman Empirle, London, 1996.

[5] Persian Gulf, hand books Prepared under the Direction Historical Section of the Foreign Office-No.76, Published by H. M. Stationery office, London, 1920.

\section{Articles (in Arabic)}

[1] Heller Josef. The British policy in Iraq before World War I. Trans. Mustafa Numan Ahmed, Afaq Arabya Journal, 21, 1996.

[2] Eluzbaki, Tawfiq Sultan. General features of colonization rapacity in the Arab Gulf between the sixteen and twentieth centuries. Adab Al-Rafdein Journal, No. 8, 1977.

[3] Al-Assadi, Riadh Jasim M. The German activity in the Arab Gulf (1900-1914). Dirasat Tarikhiya Journal, No. 7374, 2001.

[4] Al-Horani, Abdulzahra Mugtuf. Lights on the German penetration in Iraq according to the British documents. Dirasat Tarikhiya Journal, N0. 13, 2002.

[5] Al-Bidairi, Ali Hussein. The German Reich and the Baghdad Railway: A historical reading of the press stance and public opinion 1899-1903. DirasatTarikhiya Journal, No. 29, 2011.

[6] Kashif Alghitta, Ali. The role of the British policy in the penetration of the British influence in Iraq during the Ottoman reign. Afaq Arabya Journal, 22, 1977.

[7] Abdulaziz, Kuma. The Railway in Iraq until the end of World War I. Adab Al-Rafidain Journal, No. 45, 2007.

[8] Al-Tikriti, Hashim Salih. The German penetration in the Arab East before World War I. Al-Muarikh Al-Arabi Journal, No. 26, 1985.

\section{Encyclopedias (in Arabic)}

[1] Palmer Now: Encyclopedia of Modern History 1789-1945. Trans. Susan Faisal Al-Samer and Yusif M. Amin, Vol. 2, Dar Al-Mamoon, Baghdad, 1992.

[2] Al-Mudaris, Surai M. The development of navigation in Shat Al-Arab. Modern Encyclopedia of Basra, Publications of Basra University nd.

\section{Newspaper and Magazines(in Arabic)}

[1] Ssada Babel, No. 48, April, 2, 1911.

[2] Ssada Babel, No. 246, July, 1, 1914.

[3] Lughat Al-Arab, Vol.4, No, 2, December, 1912. 